\title{
Managing Peri-Implant Bone Loss: Current Understanding
}

\author{
Manar Aljateeli, DDS; ${ }^{*}$ Jia-Hui Fu, BDS; ${ }^{*}$ Hom-Lay Wang, PhD, MS, DDS ${ }^{\dagger}$
}

\begin{abstract}
Purpose: With the improved macro- and micro-designs, dental implants enjoy a high survival rate. However, peri-implant bone loss has recently emerged to be the focus of implant therapy. As such, researchers and clinicians are in need of finding predictable techniques to treat peri-implant bone loss and stop its progression.

Materials and Methods: Literature search on the currently available treatment modalities was performed and a brief description of each modality was provided.

Results: Numerous techniques have been proposed and none has been shown to be superior and effective in managing peri-implant bone loss. This may be because of the complex of etiological factors acting on the implant-supported prosthesis hence the treatment approach has to be individually tailored.

Conclusion: Due to the lack of high-level clinical evidence on the management of peri-implant bone loss, the authors, through a literature review, attempt to suggest a decision tree or guideline, based on sound periodontal surgical principles, to aid clinicians in managing peri-implantitis associated bone loss.
\end{abstract}

KEY WORDS: alveolar bone loss, bone regeneration, dental implant, peri-implantitis

\section{INTRODUCTION}

Retention of a tooth is often an ideal clinical scenario; however, when its long-term prognosis is hopeless, both the patient and clinician are faced with the challenges associated to have it replaced. In these instances, several options are available, such as fabricating a removable partial denture, a fixed partial denture, or an implantsupported prosthesis (ISP). Considering the high success or survival rates of dental implants, it is often the

${ }^{*}$ Resident, Department of Periodontics and Oral Medicine, School of Dentistry, University of Michigan, Ann Arbor, MI, USA; ${ }^{\dagger}$ professor and director of Graduate Periodontics, Department of Periodontics and Oral Medicine, School of Dentistry, University of Michigan, Ann Arbor, MI, USA

Reprint requests: Prof. Hom-Lay Wang, Department of Periodontics and Oral Medicine, School of Dentistry, University of Michigan, 1011 North University Avenue, Ann Arbor, MI 48109-1078, USA; e-mail: homlay@umich.edu

Disclaimers: The authors do not have any financial interests, either directly or indirectly, in the products or information listed in the paper.

Sources of Support: This paper was partially supported by the University of Michigan Periodontal Graduate Student Research Fund.

(C) 2011 Wiley Periodicals, Inc.

DOI 10.1111/j.1708-8208.2011.00387.x preferred choice of treatment. ${ }^{1-4}$ Unfortunately, dental implants are not miracle tooth replacements and with the increased rate of implant placement, having knowledge in the management of implant complications is very crucial.

According to the International Congress of Oral Implantologists Pisa Consensus Conference report, implant failure refers to implants that were lost or removed. ${ }^{5}$ The authors of this report suggested that the term "failure" can be applied to an implant, which has pain on function, mobility, radiographic bone loss greater than half of the implant length, uncontrolled exudates, or if it is no longer in the mouth. ${ }^{5}$ The term "implant complication", on the other hand, is applied when there is an unexpected deviation from the standard treatment outcome, ${ }^{6}$ and further treatment is required after delivery of the prosthesis. ${ }^{7}$

One of the most challenging implant complications to deal with is peri-implantitis, which is defined as a localized lesion involving bone loss around an osseointegrated implant. ${ }^{5}$ Various studies published in the last 8 years (2003-2011) looked at the success and survival rates of dental implants after at least 10 years of functional loading and found that the mean survival rate ranged from $89 \%$ to $95 \% .^{8-13}$ Despite the high long-term 
survival rates, dental implants are plagued with biological and mechanical complications. A systematic review of 51 prospective longitudinal studies reported an incidence of peri-implantitis ranging from $0 \%$ to $14.4 \%$ around functional implants with a minimum of 5 years follow-up. ${ }^{14}$ Other longitudinal studies, on the contrary, found substantial variation in the prevalence of periimplantitis, ranging from $11.3 \%$ to $47.1 \%{ }^{8,15-17}$ and a cumulative complication rate of $48.03 \%$ after a follow-up period of $10-16$ years was observed. ${ }^{8}$

Peri-implantitis can be caused by mechanical ${ }^{18}$ or biological ${ }^{19}$ factors. Occlusal overloading is a common mechanical complication that results from an interplay of several factors including poor prosthetic design, ${ }^{20}$ inadequate number, dimensions and distribution of implant fixtures, ${ }^{21}$ non-ideal implant positions, ${ }^{22}$ and parafunctional habits of patients. ${ }^{23,24}$ The clinical consequences of which are fractures of implant fixture, abutment screws, prostheses and their attachments and acrylic resin or ceramic veneers, prosthesis or abutment screw loosening, early or late implant failure, and periimplant marginal bone loss. ${ }^{25}$

Similar to periodontitis, microbial pathogens in dental plaque is the main biological cause of periimplantitis. ${ }^{26}$ It was found that supra- and sub-gingival biofilms in sites with peri-implantitis had higher counts of red complex periopathogens such as Porphyromonas gingivalis, Treponema denticola, and Tannerella forsythia. ${ }^{27,28}$ In addition, the number of beneficial microbial complexes was reduced. ${ }^{27}$ Thus, creating an environment favorable for progressive bacterial-induced peri-implant marginal bone loss. Other environmental and patient-related factors may contribute to periimplant bone loss. For example, smoking was found to be a potent risk factor that adversely affects implant success and survival rates. ${ }^{29,30}$ Patient-related factors such as systemic diseases like uncontrolled diabetes, ${ }^{31,32}$ age $^{33}$ gender $^{34}$ and history of periodontitis ${ }^{34,35}$ have been shown to contribute to peri-implant bone loss. Other biological factors include compression necrosis, ${ }^{36}$ infection, ${ }^{37}$ and overheating of the bone during implant site preparation. ${ }^{38}$

With the loss of supporting bone around a dental implant, patients may have to face the eventual consequence of implant loss. This translates to the loss of quality of life, function, esthetics, time, and money, which can also cause psychosocial stress on the patients. ${ }^{39-43}$ As such, managing peri-implant bone loss has become the focus of many researchers, and several studies have been conducted to find the optimum treatment with a goal of achieving reosseointegration along the previously contaminated implant surface. ${ }^{44-46}$ This article is aimed at discussing the effect of guided bone regeneration (GBR) in the management of peri-implant bone loss. A decision tree based on current evidence was proposed by authors to serve as a guide for clinicians to follow when managing peri-implant bone loss.

\section{PERIODONTAL DEFECTS VERSUS PERI-IMPLANT DEFECTS}

Periodontal defects can be categorized into suprabony, intrabony, or inter-radicular defects. ${ }^{47}$ They have been commonly described by the number of osseous walls, which is 4-walls or circumferential, 3-walls, 2-walls, 1-wall, or combination defects. ${ }^{48}$ The number of osseous walls surrounding the defect serves as an indication of the regenerative potential of the site. ${ }^{49}$ In natural dentition, intrabony defects frequently develop in posterior interproximal surfaces. ${ }^{50}$ Periimplant defects, on the other hand, are mainly combined defects that have supracrestal and intrabony components, with $55 \%$ of them being circumferential defects. ${ }^{51} \mathrm{~A}$ review on surgical treatment of periimplant defects concurred that peri-implant defects were well-demarcated craters. ${ }^{52}$

Different research groups have adopted the concept from periodontal defects and attempted to classify periimplant defects based on the number of remaining osseous walls. In a retrospective study of 75 patients with peri-implantitis, no or 1-wall defects corresponded to having less than $33 \%$ of surrounding bone, 2-wall defects had $33-67 \%$ of surrounding bone, and 3-wall defects had more than $67 \%$ of surrounding bone. ${ }^{53}$ Using human and animal peri-implantitis models, Schwarz and colleagues classified peri-implant osseous defects into two main categories: Class I being intrabony defects with five subcategories of class 1a to 1e, and class II being suprabony defects. ${ }^{51}$ Class $1 \mathrm{a}$ is dehiscence type defect, class $1 \mathrm{~b}$ has buccal and interproximal bone loss, and class $1 \mathrm{c}$ is an extension of class $1 \mathrm{~b}$ defects with bone loss on the lingual side of the implant. Class 1d has buccal and lingual dehiscences and interproximal bone loss and, lastly, class 1e is a well-defined circumferential defect. ${ }^{51}$ Similar to 4 -wall periodontal osseous defects, it was found that class 1e defects had the greatest regenerative potential. ${ }^{51,54}$ 


\section{AVAILABLE TREATMENT MODALITIES}

Given the similarities between periodontitis and periimplantitis, treatment modalities proposed for the management of peri-implantitis emulate techniques used to treat periodontitis. These techniques can be broadly classified into nonsurgical (e.g., antimicrobial therapy and mechanical debridement), surgical (e.g., surgical debridement, implantoplasty, and dental lasers), and regenerative therapies (e.g., GBR) with common goals of eliminating infection and restoring lost structures and function.

\section{Nonsurgical Therapy}

Human clinical trials demonstrated that locally delivered tetracycline combined with nonsurgical debridement in peri-implantitis sites improved clinical and microbiological parameters. However, the radiographic bone fill reported as $6 \%{ }^{55}$ and $0.2-0.3 \mathrm{~mm}^{56}$ was clinically insignificant. Mechanical nonsurgical treatment was also found to be ineffective in the management of peri-implantitis lesions in various reviews and clinical trials. ${ }^{57-60}$ Therefore, surgical and regenerative treatment modalities were generally preferred.

\section{Surface Decontamination}

The goals of surface decontamination are to remove etiological factors, for example, pathogenic bacteria and create a pristine surface for reosseointegration. Several agents including saline, ${ }^{61}$ abrasive pumice, ${ }^{62}$ citric acid, ${ }^{63}$ chlorhexdine, ${ }^{64}$ air-power abrasive, ${ }^{65}$ hydrogen peroxide, ${ }^{66}$ and antimicrobials ${ }^{66}$ have been used for surface decontamination in the surgical management of peri-implantitis lesions but no agent was found to be superior. Animal studies evaluating the efficacy of delmopinol, ${ }^{67}$ abrasive pumice, and saline ${ }^{62}$ showed that despite resolution of peri-implantitis, reosseointegration was not achieved. It was only when the coronal component of the implant was replaced that new bone formation was observed to be in contact with the newly placed implant part. ${ }^{61} \mathrm{~A}$ recent randomized controlled clinical trial failed to show a significant impact of surface decontamination in the treatment of periimplantitis. ${ }^{68}$ However, surface decontamination with surgical debridement was found to have a favorable influence on reosseointegration in a systematic review. $^{45}$

Dental lasers and photodynamic therapy have been used in the decontamination of implant surfaces during surgical and regenerative treatment of peri-implantitis lesions. Carbon dioxide laser was found to be effective in eliminating bacterial pathogens, specifically Streptococcus sanguis and Porphyromonas gingivalis, from titanium implant surfaces without causing surface alterations, rising the temperature or even inhibiting cell adhesion to the irradiated area ${ }^{69}$ Similar results were found by other researchers utilizing Nd:YAG, ${ }^{70}$ Er:YAG ${ }^{71}$ and diode $^{72}$ lasers. Laser therapy in combination with bone graft and collagen membrane achieved "almost complete" bone fill in the peri-implant defect. ${ }^{73,74}$ However, the long-term benefits of laser assisted treatment of peri-implant defects was not significant. ${ }^{68,75}$

Implantoplasty is also a form of surface decontamination as it involves eliminating the implant threads to achieve a smooth polished surface to decontaminate and reduce the ability of plaque to adhere to the implant surface. $^{76,77}$ There are several clinical difficulties associated with implantoplasty, namely an increase in temperature generated when drilling, which might injure the surrounding tissues and affect the strength of the implant, ${ }^{78}$ scattering of the metallic debris that might get embedded in the tissue and reduced esthetic outcome. It was found that if premium diamond burs were used with adequate coolants, there was only a $1.5^{\circ} \mathrm{C}$ increase in temperature, which was not damaging for the surrounding tissues. ${ }^{79}$ The use of a rubber dam to isolate the implant from the surrounding tissues and a high vacuum suction would minimize scattering of the metallic debris.

\section{Surgical Debridement}

Results of a recent systematic review from 25 animal studies showed that open debridement combined with surface decontamination of implants might result in reosseointegration, which was also found to be more pronounced on rougher surfaces compared with smooth surfaces. ${ }^{45}$ However, it was concluded that none of the different techniques used in managing contaminating implant surfaces was able to achieve a complete reosseointegration along the treated implant surface.

\section{Regenerative Procedures}

Human studies ${ }^{80,81}$ have been carried out to evaluate the effects of regenerative procedures in the treatment of peri-implantitis. Surgical reentry examinations showed that GBR resulted in the highest new bone fill, followed by bone grafts alone, and flap debridement only. 
However, no significant difference was found between GBR and GBR combined with bone graft. ${ }^{82}$ The results were confirmed by a subsequent study revealing similar and more detailed histological findings. ${ }^{83}$

A recent systematic review revealed that GBR could be used in the management of peri-implant bone loss, but complete fill of the bony defect was not predictable. ${ }^{84}$ Several limitations such as heterogeneity of the study protocols, missing data, and lack of highquality studies were highlighted in the review. ${ }^{84}$ Previous reviews too found that regenerative procedures involving bone grafts with or without barrier membranes demonstrated varying degrees of defect resolution and could possibly be one of the more predictable treatment modality in selected cases of peri-implantitis. ${ }^{85,86}$ Therefore, in the proposed guideline, GBR was chosen as the main treatment modality in the management of periimplant bone loss.

\section{DECISION TREE}

Current literature discussed numerous techniques used in the management of peri-implantitis defects. However, because of limitations in the available systematic reviews, there is no consensus on the most effective way to treat peri-implant bone loss. ${ }^{87}$ The authors thus propose a decision tree to assist clinicians in deciding the treatment modality to use when faced with a periimplant bone defect (Figure 1). Similar to periodontal defects, the first step in managing peri-implant defects is to identify and remove the etiological factors, which can be classified into biological factors, biomechanical factors, and a combination of both factors. Unfortunately in some circumstances, elimination of etiological factors involves removal of the dental implant. For example, when the implant is placed out of the buccal bony housing, regeneration of the buccal bone and

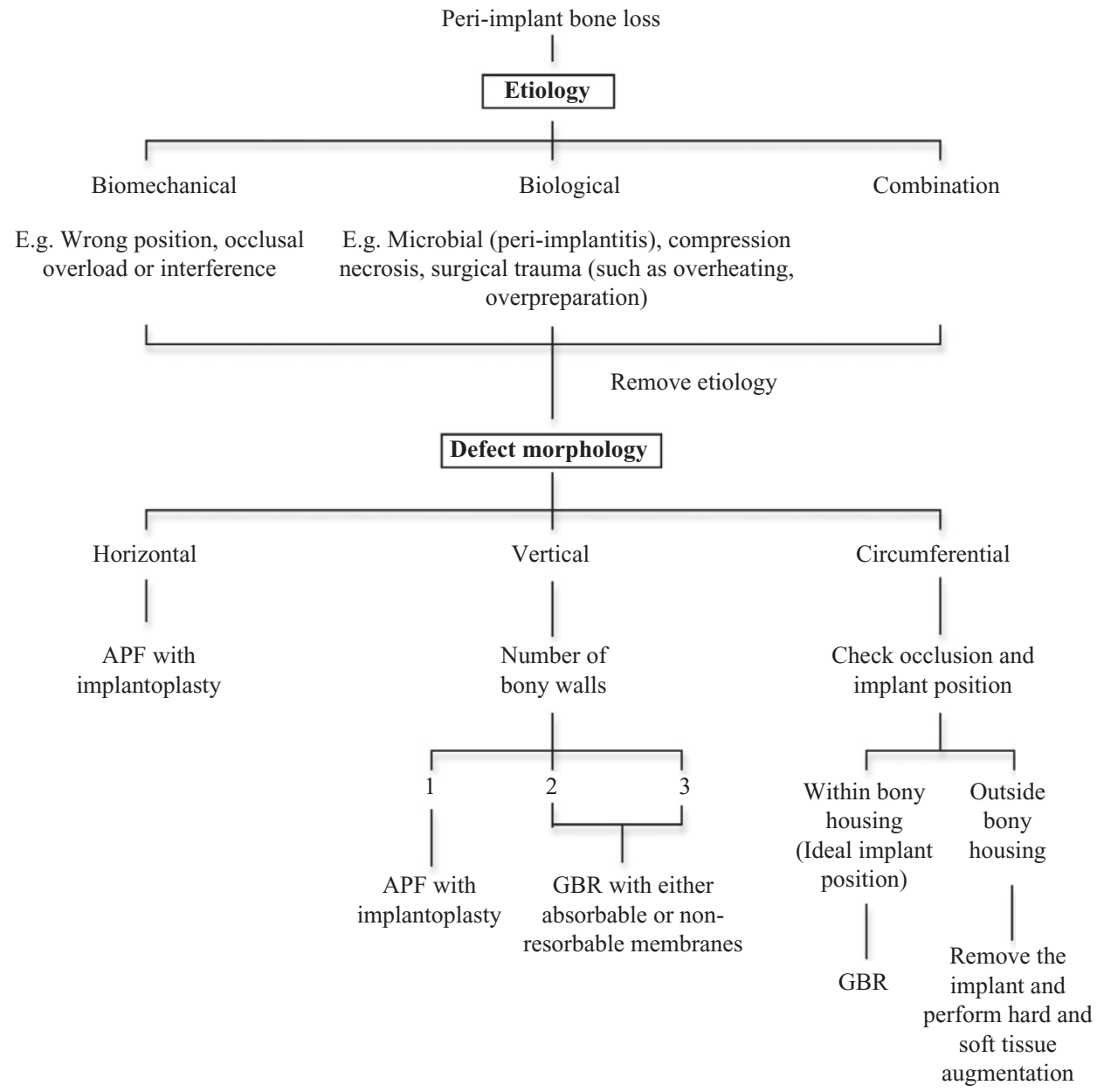

Figure 1 Decision tree on etiology and management of peri-implant bone loss. APR = apically positioned flap; GBR = guided bone regeneration. 
maintenance of its stability under functional loading is highly unpredictable. Therefore, removal of the implant and performing both hard and soft tissue augmentations would help in rebuilding the edentulous ridge for the placement of another implant. If mechanical overload is the cause of peri-implant bone loss, adjustment of occlusion or changing the prosthesis might alleviate the occlusal trauma on the surrounding bone, hence removing the biomechanical causative factor (Figure 1).

Nonsurgical therapy is commonly part of initial phase therapy with the primary goal of eliminating or reducing peri-implant inflammation and bone loss. A double-blind randomized longitudinal clinical study showed that mechanical nonsurgical treatment of periimplantitis, either with titanium hand instruments or with ultrasonic device, although improved plaque and bleeding scores, both approaches had no effect on probing implant pocket depths and total bacterial count. ${ }^{58}$ The inability of nonsurgical approach to eliminate bacteria was further supported by another singleblinded randomized longitudinal study. ${ }^{88}$ From these results, one can conclude that mechanical nonsurgical therapy alone is not effective in managing the periimplantitis, and surgical treatment remains the preferred approach.

Similar to the treatment of periodontal defects, peri-implant defects can be categorized into horizontal, vertical, and circumferential defects. The management of these defects is based on the principles set out by Ochsenbein 25 years ago. ${ }^{89}$ The lack of clinical evidence suggested that achieving bone regeneration and reosseointegration in horizontal bone defects is unpredictable. Therefore, the authors proposed performing an apically positioned flap to reduce peri-implant probing pocket depths and facilitate the formation of a more aerobic and less pathogenic biofilm..$^{90}$ However, many systems have moved to a roughened implant surface possibly because of a more predictable and stable bone to implant relationship. ${ }^{91,92}$ Therefore, once these roughened surfaces are exposed to the oral environment, there is a significant increase in surface area available for plaque retention that may influence the health of periimplant tissues. As such, the authors proposed performing implantoplasty to create a smooth surface that is less plaque retentive, thus slowing down the progression of peri-implant bone loss. ${ }^{76}$

The regenerative potential of vertical defects is dependent on several factors, namely patient-related factors such as oral hygiene ${ }^{93}$ and smoking, ${ }^{94}$ systemic conditions such as uncontrolled diabetes, ${ }^{95}$ and defect related factors such as extent of bone loss, number of defect walls, width and depth of defect. ${ }^{96}$ Patients with good oral hygiene have a reduced quantity of bacterial insults, which implies a lowered progression of the breakdown of peri-implant tissues. In addition, good oral hygiene is beneficial in achieving and maintaining disease resolution..$^{93}$ Smoking has been associated with reduced bone regeneration because of a decrease in angiogenesis and blood flow to the regenerative site. ${ }^{97} \mathrm{In}$ addition, there is a negative effect on epithelial proliferation and healing resulting in an increased in flap dehiscence and incision line opening. ${ }^{98}$ Uncontrolled diabetes mellitus results in hyperglycemia, which adversely affects osteoblast proliferation and collagen turnover. Combined with increased osteoclastic action and release of pro-inflammatory cytokines, there is more bone resorption than bone formation resulting in bone loss. ${ }^{95}$ Therefore, prior to performing GBR in periimplantitis lesions, it is beneficial to have all patientrelated factors under control.

The authors chose the number of defect walls as the primary determining factor in the management of vertical peri-implant bone defects after considering surgical principles proposed by Ochsenbein ${ }^{89}$ and Cortellini and Tonetti. ${ }^{96}$ An apically positioned flap with implantoplasty for 1-wall peri-implant bone defects is suggested because of its reduced potential to regenerate. Two- and 3-wall peri-implant bone defects have higher regenerative potential; therefore, GBR is recommended. ${ }^{99,100}$ In 2-wall defects, the bone graft will be placed in a noncontained site, therefore a non-resorbable membrane, for example, ePTFE or PTFE, will be a more suited choice as it can hold and maintain space for extended periods of time. In 3-wall defects, the bone graft will be contained within the bony walls, hence an absorbable membrane will be sufficient.

Circumferential defects are commonly seen around dental implants and believed to be caused primarily by occlusal overloading as found around the natural dentition that are subjected to trauma from occlusion. In these cases, it is important to relieve heavy occlusal contacts when the ISP is under axial and non-axial loading. The implant position within the arch is also of paramount importance as it determines the feasibility of bone regeneration around the implant. ${ }^{101}$ If the implant position is not ideal, it is recommended to have the 
implant removed and the site regrafted with bone grafts and soft tissue grafts. The implant will be placed after the grafts have healed. When the implant is determined to be in an ideal three-dimensional position, the circumferential peri-implant bone defect can be regenerated with GBR. The use of a non-resorbable or absorbable membrane will suffice.

Following the "PASS" principle, where primary wound closure is paramount in ensuring a stable protected environment for optimal bone regeneration, it would be ideal that the suprastructures, for example, the abutment and prosthesis were removed and the regenerative site was left to heal under a closed environment. ${ }^{102}$ Removal of the suprastructures might prove to be a challenge for cemented prosthesis, and alternatives available are fabrication of a new prosthesis or conversion of the cemented prosthesis to a screw retained one. The inability to achieve primary wound closure around a restoration provided a pathway for bacteria or foreign bodies to reach the regenerative site resulting in compromised bone regeneration. ${ }^{103,104}$

Although the treatment and resolution of periimplantitis remains highly unpredictable with the current available treatment options, some studies had demonstrated promising results. ${ }^{60,84,87}$ In the light of the studies reviewed, open debridement and regeneration procedures have, by far, shown to demonstrate superior and more consistent results compared with the other currently available treatment modalities. Antimicrobial therapy and surface decontamination were shown to resolve peri-implantitis but they failed to achieve significant reosseointegration, which was the main goal of the treatment. In addition, most of the studies available used antimicrobial followed by mechanical debridement and local or systemic antibiotics administration, making it difficult to conclude the true individual effectiveness of antimicrobial therapy or surface decontamination. More randomized controlled studies should be conducted to assess the efficacy and the exact benefit of the available treatment options. Future research should be directed at determining a standard optimum treatment for more predictable reosseointegration. The inconsistency of the results in different studies could be due to the great variability in methodologies, measured parameters, implant design, surface characteristics of implants, ligatures placement and removal time period, defect morphology, and defect size. Until more evidence is available, the use of antimicrobial therapy, or using one decontamination agent over the other is not really strongly supported. With the current lack of sufficient and consistent documentation, especially lack of human studies, a single best treatment cannot be pointed out. Therefore, it is very important to highlight the necessity of regular maintenance visits to monitor the progression of disease and the effectiveness of therapy. If peri-implant bone loss takes place, the decision of treatment should be based on a patientby-patient situation. Hence, the authors suggested a straightforward decision tree to provide clinicians a reference when dealing with peri-implant bone loss.

\section{CONCLUSION}

Over the past 20 years, dentistry saw a paradigm shift in the management of patients with missing teeth with the introduction of dental implants. Today, seeking a predictable method to treat peri-implant bone loss and achieve reosseointegration is the latest advancement in implant dentistry. Although it is known that periimplant bone loss is caused by biological, biomechanical, or a combination of factors similar to periodontal disease around teeth, the predictability of treatment modalities to manage these defects remains uncertain. Numerous methodologies have been proposed over time to treat peri-implant bone loss and retard its progression; however, there is no consensus on which technique is the most effective. Therefore, the authors, through a literature review, suggest a straightforward decision tree to help clinicians manage peri-implant bone loss.

\section{REFERENCES}

1. Jemt T, Lekholm U, Adell R. Osseointegrated implants in the treatment of partially edentulous patients: a preliminary study on 876 consecutively placed fixtures. Int J Oral Maxillofac Implants 1989; 4:211-217.

2. Bahat O. Treatment planning and placement of implants in the posterior maxillae: report of 732 consecutive Nobelpharma implants. Int J Oral Maxillofac Implants 1993; 8:151-161.

3. Nevins M, Langer B. The successful application of osseointegrated implants to the posterior jaw: a long-term retrospective study. Int J Oral Maxillofac Implants 1993; 8:428-432.

4. Nevins M, Langer B. The successful use of osseointegrated implants for the treatment of the recalcitrant periodontal patient. J Periodontol 1995; 66:150-157. 
5. Misch CE, Perel ML, Wang HL, et al. Implant success, survival, and failure: the International Congress of Oral Implantologists (ICOI) Pisa Consensus Conference. Implant Dent 2008; 17:5-15.

6. Laney W. Glossary of oral and maxillofacial implants. Berlin: Quintessence, 2007.

7. Lang NP, Berglundh T, Heitz-Mayfield LJ, Pjetursson BE, Salvi GE, Sanz M. Consensus statements and recommended clinical procedures regarding implant survival and complications. Int J Oral Maxillofac Implants 2004; 19(Suppl):150-154.

8. Simonis P, Dufour T, Tenenbaum H. Long-term implant survival and success: a 10-16-year follow-up of nonsubmerged dental implants. Clin Oral Implants Res 2010; 21:772-777.

9. Karoussis IK, Bragger U, Salvi GE, Burgin W, Lang NP. Effect of implant design on survival and success rates of titanium oral implants: a 10-year prospective cohort study of the ITI Dental Implant System. Clin Oral Implants Res 2004; 15:8-17.

10. Roccuzzo M, De Angelis N, Bonino L, Aglietta M. Ten-year results of a three-arm prospective cohort study on implants in periodontally compromised patients. Part 1: implant loss and radiographic bone loss. Clin Oral Implants Res 2010; 21:490-496.

11. Lekholm U, Grondahl K, Jemt T. Outcome of oral implant treatment in partially edentulous jaws followed 20 years in clinical function. Clin Implant Dent Relat Res 2006; 8:178186.

12. Karoussis IK, Salvi GE, Heitz-Mayfield LJ, Bragger U, Hammerle CH, Lang NP. Long-term implant prognosis in patients with and without a history of chronic periodontitis: a 10-year prospective cohort study of the ITI Dental Implant System. Clin Oral Implants Res 2003; 14:329-339.

13. Ferrigno N, Laureti M, Fanali S. Dental implants placement in conjunction with osteotome sinus floor elevation: a 12-year life-table analysis from a prospective study on 588 ITI implants. Clin Oral Implants Res 2006; 17:194-205.

14. Berglundh T, Persson L, Klinge B. A systematic review of the incidence of biological and technical complications in implant dentistry reported in prospective longitudinal studies of at least 5 years. J Clin Periodontol 2002; 29(Suppl 3):197-212.

15. Koldsland OC, Scheie AA, Aass AM. Prevalence of periimplantitis related to severity of the disease with different degrees of bone loss. J Periodontol 2010; 81:231-238.

16. Zitzmann NU, Berglundh T. Definition and prevalence of peri-implant diseases. J Clin Periodontol 2008; 35:286291.

17. Roos-Jansaker AM, Lindahl C, Renvert H, Renvert S. Nineto fourteen-year follow-up of implant treatment. Part II: presence of peri-implant lesions. J Clin Periodontol 2006; 33:290-295.
18. Salvi GE, Bragger U. Mechanical and technical risks in implant therapy. Int J Oral Maxillofac Implants 2009; 24(Suppl):69-85.

19. Lang NP, Wilson TG, Corbet EF. Biological complications with dental implants: their prevention, diagnosis and treatment. Clin Oral Implants Res 2000; 11(Suppl 1):146-155.

20. Zurdo J, Romao C, Wennstrom JL. Survival and complication rates of implant-supported fixed partial dentures with cantilevers: a systematic review. Clin Oral Implants Res 2009; 20(Suppl 4):59-66.

21. Guan H, van Staden R, Loo YC, Johnson N, Ivanovski S, Meredith N. Evaluation of multiple implant-bone parameters on stress characteristics in the mandible under traumatic loading conditions. Int J Oral Maxillofac Implants 2010; 25:461-472.

22. Cardaropoli G, Wennstrom JL, Lekholm U. Peri-implant bone alterations in relation to inter-unit distances. A 3-year retrospective study. Clin Oral Implants Res 2003; 14:430 436.

23. Wahlstrom M, Sagulin GB, Jansson LE. Clinical follow-up of unilateral, fixed dental prosthesis on maxillary implants. Clin Oral Implants Res 2010; 21:1294-1300.

24. Kinsel RP, Lin D. Retrospective analysis of porcelain failures of metal ceramic crowns and fixed partial dentures supported by 729 implants in 152 patients: patient-specific and implant-specific predictors of ceramic failure. J Prosthet Dent 2009; 101:388-394.

25. Goodacre CJ, Bernal G, Rungcharassaeng K, Kan JY. Clinical complications with implants and implant prostheses. J Prosthet Dent 2003; 90:121-132.

26. Mombelli A, van Oosten MA, Schurch E, Jr, Land NP. The microbiota associated with successful or failing osseointegrated titanium implants. Oral Microbiol Immunol 1987; 2:145-151.

27. Shibli JA, Melo L, Ferrari DS, Figueiredo LC, Faveri M, Feres M. Composition of supra- and subgingival biofilm of subjects with healthy and diseased implants. Clin Oral Implants Res 2008; 19:975-982.

28. Leonhardt A, Renvert S, Dahlen G. Microbial findings at failing implants. Clin Oral Implants Res 1999; 10:339345.

29. Strietzel FP, Reichart PA, Kale A, Kulkarni M, Wegner B, Kuchler I. Smoking interferes with the prognosis of dental implant treatment: a systematic review and meta-analysis. J Clin Periodontol 2007; 34:523-544.

30. Heitz-Mayfield LJ. Peri-implant diseases: diagnosis and risk indicators. J Clin Periodontol 2008; 35:292-304.

31. Lindhe J, Meyle J. Peri-implant diseases: consensus report of the sixth european Workshop on periodontology. J Clin Periodontol 2008; 35:282-285.

32. Ferreira SD, Silva GL, Cortelli JR, Costa JE, Costa FO. Prevalence and risk variables for peri-implant disease in Brazilian subjects. J Clin Periodontol 2006; 33:929-935. 
33. Brocard D, Barthet $\mathrm{P}$, Baysse $\mathrm{E}$, et al. A multicenter report on 1,022 consecutively placed ITI implants: a 7-year longitudinal study. Int J Oral Maxillofac Implants 2000; 15:691-700.

34. Koldsland OC, Scheie AA, Aass AM. The association between selected risk indicators and severity of periimplantitis using mixed model analyses. J Clin Periodontol 2011; 38:285-292.

35. Heitz-Mayfield LJ, Huynh-Ba G. History of treated periodontitis and smoking as risks for implant therapy. Int J Oral Maxillofac Implants 2009; 24(Suppl):39-68.

36. Bashutski JD, D'Silva NJ, Wang HL. Implant compression necrosis: current understanding and case report. J Periodontol 2009; 80:700-704.

37. Paquette DW, Brodala N, Williams RC. Risk factors for endosseous dental implant failure. Dent Clin North Am 2006; 50:361-374.

38. Eriksson AR, Albrektsson T, Albrektsson B. Heat caused by drilling cortical bone. Temperature measured in vivo in patients and animals. Acta Orthop Scand 1984; 55:629631.

39. Meijer HJ, Raghoebar GM, Van't Hof MA. Comparison of implant-retained mandibular overdentures and conventional complete dentures: a 10-year prospective study of clinical aspects and patient satisfaction. Int J Oral Maxillofac Implants 2003; 18:879-885.

40. Heydecke G, Thomason JM, Lund JP, Feine JS. The impact of conventional and implant supported prostheses on social and sexual activities in edentulous adults Results from a randomized trial 2 months after treatment. J Dent 2005; 33:649-657.

41. Awad MA, Locker D, Korner-Bitensky N, Feine JS. Measuring the effect of intra-oral implant rehabilitation on healthrelated quality of life in a randomized controlled clinical trial. J Dent Res 2000; 79:1659-1663.

42. Awad MA, Lund JP, Shapiro SH, et al. Oral health status and treatment satisfaction with mandibular implant overdentures and conventional dentures: a randomized clinical trial in a senior population. Int J Prosthodont 2003; 16:390396.

43. Awad MA, Lund JP, Dufresne E, Feine JS. Comparing the efficacy of mandibular implant-retained overdentures and conventional dentures among middle-aged edentulous patients: satisfaction and functional assessment. Int J Prosthodont 2003; 16:117-122.

44. Parlar A, Bosshardt DD, Cetiner D, et al. Effects of decontamination and implant surface characteristics on re-osseointegration following treatment of periimplantitis. Clin Oral Implants Res 2009; 20:391-399.

45. Renvert S, Polyzois I, Maguire R. Re-osseointegration on previously contaminated surfaces: a systematic review. Clin Oral Implants Res 2009; 20(Suppl 4):216-227.

46. Alhag M, Renvert S, Polyzois I, Claffey N. Reosseointegration on rough implant surfaces previously coated with bacterial biofilm: an experimental study in the dog. Clin Oral Implants Res 2008; 19:182-187.

47. Papapanou PN, Tonetti MS. Diagnosis and epidemiology of periodontal osseous lesions. Periodontol 2000 2000; 22:821.

48. Goldman H, Cohen W. The intrabony pocket, classification and treatment. J Periodontol 1958; 29:272-281.

49. Weinberg MA, Eskow RN. Osseous defects: proper terminology revisited. J Periodontol 2000; 71:1928.

50. Larato DC. Intrabony defects in the dry human skull. J Periodontol 1970; 41:496-498.

51. Schwarz F, Herten M, Sager M, Bieling K, Sculean A, Becker J. Comparison of naturally occurring and ligature-induced peri-implantitis bone defects in humans and dogs. Clin Oral Implants Res 2007; 18:161-170.

52. Schou S, Berglundh T, Lang NP. Surgical treatment of peri-implantitis. Int J Oral Maxillofac Implants 2004; 19(Suppl):140-149.

53. Zitzmann NU, Scharer P, Marinello CP. Factors influencing the success of GBR. Smoking, timing of implant placement, implant location, bone quality and provisional restoration. J Clin Periodontol 1999; 26:673-682.

54. Schwarz F, Sahm N, Schwarz K, Becker J. Impact of defect configuration on the clinical outcome following surgical regenerative therapy of peri-implantitis. J Clin Periodontol 2010; 37:449-455.

55. Mombelli A, Feloutzis A, Bragger U, Lang NP. Treatment of peri-implantitis by local delivery of tetracycline. Clinical, microbiological and radiological results. Clin Oral Implants Res 2001; 12:287-294.

56. Khoury F, Buchmann R. Surgical therapy of peri-implant disease: a 3-year follow-up study of cases treated with 3 different techniques of bone regeneration. J Periodontol 2001; 72:1498-1508.

57. Renvert S, Roos-Jansaker AM, Claffey N. Non-surgical treatment of peri-implant mucositis and peri-implantitis: a literature review. J Clin Periodontol 2008; 35:305315.

58. Renvert S, Samuelsson E, Lindahl C, Persson GR. Mechanical non-surgical treatment of peri-implantitis: a doubleblind randomized longitudinal clinical study. I: clinical results. J Clin Periodontol 2009; 36:604-609.

59. Faggion CM, Jr, Chambrone L, Gondim V, Schmitter M, Tu YK. Comparison of the effects of treatment of peri-implant infection in animal and human studies: systematic review and meta-analysis. Clin Oral Implants Res 2010; 21:137147.

60. Esposito M, Grusovin MG, Coulthard P, Worthington HV. The efficacy of interventions to treat peri-implantitis: a Cochrane systematic review of randomised controlled clinical trials. Eur J Oral Implantol 2008; 1:111-125.

61. Persson LG, Ericsson I, Berglundh T, Lindhe J. Osseintegration following treatment of peri-implantitis and 
replacement of implant components. An experimental study in the dog. J Clin Periodontol 2001; 28:258-263.

62. Persson LG, Araujo MG, Berglundh T, Grondahl K, Lindhe J. Resolution of peri-implantitis following treatment. An experimental study in the dog. Clin Oral Implants Res 1999; 10:195-203.

63. Hanisch $\mathrm{O}$, Tatakis $\mathrm{DN}$, Boskovic MM, Rohrer MD, Wikesjo UM. Bone formation and reosseointegration in peri-implantitis defects following surgical implantation of rhBMP-2. Int J Oral Maxillofac Implants 1997; 12:604610.

64. Wetzel AC, Vlassis J, Caffesse RG, Hammerle CH, Lang NP. Attempts to obtain re-osseointegration following experimental peri-implantitis in dogs. Clin Oral Implants Res 1999; 10:111-119.

65. Machado MA, Stefani CM, Sallum EA, Sallum AW, Tramontina VA, Nociti Junior FH. Treatment of ligatureinduced peri-implantitis defects by regenerative procedures: a clinical study in dogs. J Oral Sci 1999; 41:181-185.

66. Leonhardt A, Dahlen G, Renvert S. Five-year clinical, microbiological, and radiological outcome following treatment of peri-implantitis in man. J Periodontol 2003; 74:1415-1422.

67. Ericsson I, Persson LG, Berglundh T, Edlund T, Lindhe J. The effect of antimicrobial therapy on periimplantitis lesions. An experimental study in the dog. Clin Oral Implants Res 1996; 7:320-328.

68. Schwarz F, Sahm N, Iglhaut G, Becker J. Impact of the method of surface debridement and decontamination on the clinical outcome following combined surgical therapy of peri-implantitis: a randomized controlled clinical study. J Clin Periodontol 2011; 38:276-284.

69. Kato T, Kusakari H, Hoshino E. Bactericidal efficacy of carbon dioxide laser against bacteria-contaminated titanium implant and subsequent cellular adhesion to irradiated area. Lasers Surg Med 1998; 23:299-309.

70. Goncalves F, Zanetti AL, Zanetti RV, et al. Effectiveness of $980-\mathrm{mm}$ diode and 1,064-nm extra-long-pulse neodymium-doped yttrium aluminum garnet lasers in implant disinfection. Photomed Laser Surg 2010; 28:273280.

71. Kreisler M, Kohnen W, Marinello C, et al. Bactericidal effect of the Er:YAG laser on dental implant surfaces: an in vitro study. J Periodontol 2002; 73:1292-1298.

72. Dortbudak O, Haas R, Bernhart T, Mailath-Pokorny G. Lethal photosensitization for decontamination of implant surfaces in the treatment of peri-implantitis. Clin Oral Implants Res 2001; 12:104-108.

73. Azzeh MM. Er,Cr:YSGG laser-assisted surgical treatment of peri-implantitis with 1-year reentry and 18-month followup. J Periodontol 2008; 79:2000-2005.

74. Romanos GE, Nentwig GH. Regenerative therapy of deep peri-implant infrabony defects after $\mathrm{CO} 2$ laser implant surface decontamination. Int J Periodontics Restorative Dent 2008; 28:245-255.

75. Deppe $\mathrm{H}$, Horch $\mathrm{HH}$, Neff A. Conventional versus $\mathrm{CO} 2$ laser-assisted treatment of peri-implant defects with the concomitant use of pure-phase beta-tricalcium phosphate: a 5-year clinical report. Int J Oral Maxillofac Implants 2007; 22:79-86.

76. Romeo E, Lops D, Chiapasco M, Ghisolfi M, Vogel G. Therapy of peri-implantitis with resective surgery. A 3-year clinical trial on rough screw-shaped oral implants. Part II: radiographic outcome. Clin Oral Implants Res 2007; 18:179-187.

77. Romeo E, Ghisolfi M, Murgolo N, Chiapasco M, Lops D, Vogel G. Therapy of peri-implantitis with resective surgery. A 3-year clinical trial on rough screw-shaped oral implants. Part I: clinical outcome. Clin Oral Implants Res 2005; 16:918.

78. Gross M, Laufer BZ, Ormianar Z. An investigation on heat transfer to the implant-bone interface due to abutment preparation with high-speed cutting instruments. Int J Oral Maxillofac Implants 1995; 10:207-212.

79. Sharon E, Shapira L, Wilensky A, Abu-Hatoum R, Smidt A. Efficiency and thermal changes during implantoplasty in relation to bur type. Clin Implant Dent Relat Res 2011. DOI: $10.1111 /$ j.1708-8208.2011.00366.x.

80. Hammerle $\mathrm{CH}$, Fourmousis I, Winkler JR, Weigel C, Bragger U, Lang NP. Successful bone fill in late peri-implant defects using guided tissue regeneration. A short communication. J Periodontol 1995; 66:303308.

81. Mellonig JT, Triplett RG. Guided tissue regeneration and endosseous dental implants. Int J Periodontics Restorative Dent 1993; 13:108-119.

82. Hurzeler MB, Quinones CR, Morrison EC, Caffesse RG. Treatment of peri-implantitis using guided bone regeneration and bone grafts, alone or in combination, in beagle dogs. Part 1: clinical findings and histologic observations. Int J Oral Maxillofac Implants 1995; 10:474-484.

83. Hurzeler MB, Quinones CR, Schupback P, Morrison EC, Caffesse RG. Treatment of peri-implantitis using guided bone regeneration and bone grafts, alone or in combination, in beagle dogs. Part 2: histologic findings. Int J Oral Maxillofac Implants 1997; 12:168-175.

84. Sahrmann P, Attin T, Schmidlin PR. Regenerative treatment of peri-implantitis using bone substitutes and membrane: a systematic review. Clin Implant Dent Relat Res 2011; 13:46-57.

85. Claffey N, Clarke E, Polyzois I, Renvert S. Surgical treatment of peri-implantitis. J Clin Periodontol 2008; 35:316332.

86. Roos-Jansaker AM, Renvert S, Egelberg J. Treatment of peri-implant infections: a literature review. J Clin Periodontol 2003; 30:467-485. 
87. Faggion CM, Jr, Schmitter M. Using the best available evidence to support clinical decisions in implant dentistry. Int J Oral Maxillofac Implants 2010; 25:960-969.

88. Persson GR, Samuelsson E, Lindahl C, Renvert S. Mechanical non-surgical treatment of peri-implantitis: a singleblinded randomized longitudinal clinical study. II. Microbiological results. J Clin Periodontol 2010; 37:563573.

89. Ochsenbein C. A primer for osseous surgery. Int J Periodontics Restorative Dent 1986; 6:8-47.

90. Greenstein G. Contemporary interpretation of probing depth assessments: diagnostic and therapeutic implications. A literature review. J Periodontol 1997; 68:1194-1205.

91. Junker R, Dimakis A, Thoneick M, Jansen JA. Effects of implant surface coatings and composition on bone integration: a systematic review. Clin Oral Implants Res 2009; 20(Suppl 4):185-206.

92. Zechner W, Trinkl N, Watzak G, et al. Radiologic follow-up of peri-implant bone loss around machine-surfaced and rough-surfaced interforaminal implants in the mandible functionally loaded for 3 to 7 years. Int J Oral Maxillofac Implants 2004; 19:216-221.

93. Serino G, Turri A. Outcome of surgical treatment of periimplantitis: results from a 2-year prospective clinical study in humans. Clin Oral Implants Res 2011; DOI: 10.1111/ j.1600-0501.2010.02098.x.

94. Patel RA, Wilson RF, Palmer RM. The effect of smoking on periodontal bone regeneration: a systematic review and meta-analysis. J Periodontol 2011 [Epub ahead of print].

95. Javed F, Romanos GE. Impact of diabetes mellitus and glycemic control on the osseointegration of dental implants: a systematic literature review. J Periodontol 2009; 80:1719_ 1730 .

96. Cortellini P, Tonetti MS. Focus on intrabony defects: guided tissue regeneration. Periodontol 2000 2000; 22:104132

97. Silverstein P. Smoking and wound healing. Am J Med 1992; 93:22S-24S.

98. Trombelli L, Kim CK, Zimmerman GJ, Wikesjo UM. Retrospective analysis of factors related to clinical outcome of guided tissue regeneration procedures in intrabony defects. J Clin Periodontol 1997; 24:366-371.

99. Lorenzoni M, Pertl C, Keil C, Wegscheider WA. Treatment of peri-implant defects with guided bone regeneration: a comparative clinical study with various membranes and bone grafts. Int J Oral Maxillofac Implants 1998; 13:639_ 646.

100. Lehmann B, Bragger U, Hammerle CH, Fourmousis I, Lang NP. Treatment of an early implant failure according to the principles of guided tissue regeneration (GTR). Clin Oral Implants Res 1992; 3:42-48.

101. Bashutski JD, Wang HL. Common implant esthetic complications. Implant Dent 2007; 16:340-348.

102. Wang HL, Boyapati L. "PASS" principles for predictable bone regeneration. Implant Dent 2006; 15:8-17.

103. Park SH, Lee KW, Oh TJ, Misch CE, Shotwell J, Wang HL. Effect of absorbable membranes on sandwich bone augmentation. Clin Oral Implants Res 2008; 19:32-41.

104. Oh TJ, Meraw SJ, Lee EJ, Giannobile WV, Wang HL. Comparative analysis of collagen membranes for the treatment of implant dehiscence defects. Clin Oral Implants Res 2003; 14:80-90. 